is a herbarium, a fair collection of butterflies and beetles and a collection of fungi from the Liverpool district, and a good collection of zoophytes from Bootle, near Liverposl. There is also a small collection of ethnographical objects, weapons, Indian remains, flint axes, \&c., and the usual miscellaneous objects of a local museum. There is a large stuffed specimen of the sea-elephant from the South Shetland Islands, which is valuable, as the species is yearly becoming much rarer. It seems a pity that some arrangement could not be made between the two museums, so that this one could be lightened of some of its heterogeneous contents, and more room given for a better display of some special collections. Besides this, those who are interested in mineralogy should not fail to visit the Medical Institution, in Hope-street, where Phillips's mineral collection is well exhibited. There is also the Museum of the Royal Infirmary School of Medicine, which is more likely to please those interested in medical pursuits than the general public.

To those botanically inclined, the extensive Botanical Gardens in Edge Lane will be very attractive. They cover an extent of about eleven or twelve acres, and are very tastefully laid out, and the large conservatories contain many fine and choice exotics.

Those who are interested in the practical application of science to the requirements of the present day, should not fail to visit the Liverpool Sewage Utilisation Works at Sandhills. These are open to all members of the Association, and will be found to afford much practical knowledge on a subject that is yearly attracting more attention.

The Liverpool scientific societies, though they have existed many years, have failed to attract very much attention, or to become prominently known. The most important of these is the Lancashireand Cheshire Historic Society, which was started about $\mathrm{I} 847$, as a purely antiquarian society in all matters relating to the two counties. It has published a set of transactions containing much valuable information; but of later years it has enlarged its scope and taken in other branches of scientific knowledge, with a result, we fear, not commensurate with the wishes of its promoters. The Liverpool Philosophical Society, and the Liverpool Geological Society, unlike the similar societies in Manchester and Leeds, are but little known outside the city in which they hold their meetings.

Soon after Owens College was founded in Manchester, a somewhat similar college, called Queen's College, was started in Liverpool; but whether owing to lack of energy or good management on the part of its directors, or from the overpowering influence of the old-established Collegiate Institution, it has certainly failed in approximating in any direction to the national importance and value that the former college has obtained.

In some degree compensating for these failures, Liverpool possesses a very extensive and much-patronised Field Naturalists' Club, which does a great deal by weekly excursions to infuse into its members a taste for natural science and out-of-door scientific work, and there is little doubt but that from all its members the British Association will receive a hearty welcome; and let us hope that from this year's meeting may date an increased impetus to Science in the neighbourhood.

\section{NOTES ON THE GEOLOGY OF THE COUNTRY} AROUND LIVERPOOL

$7 \mathrm{HE}$ following brief notes on some of the points of geological interest may perhaps be of use to geologists from the South of England visiting the British Association's Meeting at Liverpool.

The tract of country lying between the rivers Dee and Mersey, known as the peninsula of Wirral, is composed of Triassic rocks, forming a series of undulating ridges and valleys, running parallel with the strike of the rocks. The average elevation of the crest of the hills is about I 50 feet, and they, as well as the valleys, are more or less covered with glacial drifts. The northward prolongation of the hills and valleys is abruptly terminated by a broad plain, but little raised above the sea-level, which forms the seaward portion of the Hundred of Wirral. This plain. which is composed of peat partly covered with alluvium, is drained by the River Birket, which flows eastward along its whole length, from a little south of Hoylake, until it falls into Wallasey Pool, an arm of the River Mersey, which separates the tract of comparatively high land known as Wallasey (anciently an island) from the Triassic hills south of the Pool.

Crossing the Mersey, the town of Liverpool is found to rest on a continuation of the Triassic hills south of the river, but more deeply covered with drift, which has in most cases so entirely filled up the valleys that the wholc of the Coal-measure and Triassic districts of south-west Lancashire are one vast plain, surrounding a central nucleus formed by the spurs of the Pennine Chain, com. posed of the Millstone Grit.

The latter formation, on the borders of the Lancashire coal-field, reaches an average thickness of 5,000 feet, and is composed of four great beds of grit, divided from each other by thick beds of shale. These beds are known as the Rough Rock, or first grit; the Haslingden Flags, or second grit; the third grit; and the Kinder Scout, or fourth grit. The first and fourth grits are generally coarse, conglomerative, and massive ; the third, as a rule, finer and not conglomeratic-both it and the fourth grit are often divided into two, three, and even more beds of thick seams of shale, which thin, wedge out, and thicken in the most irregular and local manner. In fact, though the Millstone Grit, as a whole, maintains a general average thickness in any special area, its nembers in detail appear to be ever changing places in relative consequence with each other, proving the shallowness of the sea, the proximity of land, and the existence of currents laden with different materials, sand and pebbles washed from those deep-seated quartzites which raised their heads above the sea at the time of the deposition of the gxit in the area now occupied by the Pennine Chain.* Workable coal-seams occur in the first and third grits, and thin seams in the fourth; associated with them are shales in which a flora and fauna of about 30 species occur, the same species recurring in the different seams of shale: 18 species occur in the shales of the "Feather-edge" coal' (in the Rough Rock); amongst them are Calanites Suckowii, and Pecopteris arborescens. The former species I recently found in some shales of the second grit, exposed

* Prof. E. Hull, F.R.S., Quart. Journ. Geol. Soc., August, 2868.

+ This coal is described by Mr. E. W. Binney, F. R.S., in the Trans Geol. Soc. Man. vol. i, ; by Prof. E. Hull, F.R.S., in Geol. Surv. Mem.
"On the Geology of Oldham," and in the "Geology of Bolton-le-Moors," 
in the new excavations for the Liverpool Waterworks' upper reservoir, above Alance Bridge, north of Rivington. A little further west another bed of black shale occurs, apparently on the same horizon as that from which the Geological Survey Map (six-inch map, Lancashire, sheet 78) records the presence of Goniatites. These and other fossils also found in the shales forming the roof of two coal-seams, occurring between the second and third grits. The shales dividing the latter grit are also fossiliferous in two instances in Lancashire, and Goniatites may be found in the shales between the third and fourth grits, at Old Kates Dingle and Shore Brook, below Noon Hill, east of Rivington (reached from Adlington Station). They reach, I should say, a thickness of 600 feet, and contain two thin coal-seams. The Kinderscout grit, though nearly 1,000 feet thick, appears to be almost devoid of organic remains ; but the occasional fragments of Stigmaria testify to the existence of land during the period of its deposit, as do also the thin seams of coal.

The Coal Measures.-These are so well known through the various survey memoirs of Professor Hull, ${ }^{*}$ and papers of Mr. E. W. Binney, F.R.S., that it is needless for me to describe them. They are divided into three divisions: the upper is devoid of coal, and is absent in South-west Lancashire; the middle coal-measures contain all the valuable coals, the best being that at the base, known as the Arley Mine, which is perhaps equal to any coal in England. The sixth seam, above the Arley, is the celebrated Wigan "cannel coal :" it is three feet thick at that town, thinning out in every direction, with Wigan as a centre, as shown by Mr. Hull.

The Lower Coal Measures, or Gannister beds, from their containing siliceous concretions, locally called "Gannisters," have five or six workable coals which are known as Mountain Mines. Coal-measures occur at Neston on the west coast of Cheshire, and again at Croxteth Park, near Liverpool, and it is probable that they underlie the whole of the Triassic rocks of Wirral, and of part of Liverpool itself.

Permian.-No geologist should leave Liverpool without visiting the two Permian outliers, discovered by Professor Hull, at Skillaw Clough and in Bentley Brook, Bispham (north-east of Ormskirk); they consist of sandstones, marls, and magnesian limestone. $\dagger$

Trias, or New Red Sandstone.-This is divided into the following subdivisions :-

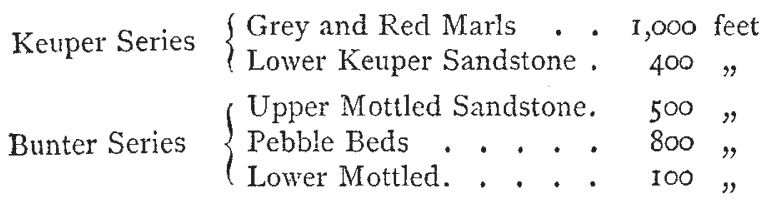

The Lower Mottled Sandstone is best seen in the Liverpool district, at Eastham, on the Cheshire side of the Mersey, where it forms a cliff capped by the Pebble Beds. The latter are well seen in the quarries at Everton, above Liverpool ; they are generally stained a deep brickred with peroxide of iron, and contain seams of quartzpebbles running along the lines of current-bedding seams of grey and red marl, which also occurs in small pockets

\footnotetext{
* Mem. Geol. Surv., "Geology of Oldham," "Geology of Wigan," "Geolugy of Bolton-le-Moors," "Geology of P'rescot."

$t$ See "Geology of Wigan," p. 27, and Geol. Sturv. Map, 8q, S.W.
}

in the rock. The Upper Mottled Sandstone is, as a rule, pebbleless, much false-bedded, streaked and mottled in its middle portion, yellow above, and deep bright red below. The latter beds are well seen at the mouth of Bromborough Pool, near Birkenhead; the middle beds at Ormskirk, where the celebrated section, first described by Mr. Hull, * occurs, where nearly level beds of conglomeratic Lower Keuper Sandstone rest on the denuded upturned edges of the variegated beds of the Upper Mottled Sandstone: it is exposed in the railway cutting leading towards St. Helen's, a little east of the town.

Lower Keuper Sandstone.--The base of this sandstone in this as in other districts, is extremely pebbly, and consists of hard grit, not unlike some of the beds of the millstone grits, and like them, and the sands and gravels of the Middle Drift Period, is much false-bedded. The middle portion consists of fine-grained freestones, separated by thin seams of grey marl, supporting water : these are well seen in the railway cutting at Orrel (east of Waterlooj, $*$ first described by the writer in the Survey Memoir on the district. The Labyrinthodon bed ( 3 to 4 feet thick) occurs near the base of this part of the Keuper Sandstone: it is best seen at Storeton, near the windmill (on the Cheshire side of the river) : many fine footprints may be seen in the Liverpool museums. In the Orrel Railway cutting, magnesia is found to occur in the shale, as well as pseudomorphous crystals of salt, which also occur in the shales at the top of the sandstone, or at the base of the marls, whichever way they may be taken; for the sandstones, shales and marls, are in reality only one series gradually passing from the one into the other, as the sea grew shallower and shallower, and became supersaturated with salt, until at length the sea became a salt lake. From this sequence there is, however, one exception in this district, which I have not noticed elsewhere. A conglomeratic bed occurs near the very top of the Keuper Sandstone, immediately below the horizon of the shales; the pebbles consist of quartz, and are apparently derived from the same source as those occurring in some of the millstone-grit beds. The existence of round pebbles in a deposit proves either the proximity of a coast line or the shallowness of the water at the period of deposition ; for unless the water is shallow, currents, I know by experience, have not the power to move pebbles. The Trias, as a whole, appears to have been formed during a period in which subsidence hardly kept pace with the deposition of sands and clays brought down by rivers from continental lands. This upper pebble bed would appear to have been thrown down at a moment when the movement of subsidence was greater than usual, causing islands of quartzites, or possibly of millstone grit, containing quartz-pebbles.

Keuper Marls.-This division attains an immense thickness in the country between Liverpool and Southport; but is so deeply covered with drift, glacial and post. glacial, that sections are very rare. Much of it, like the northern end of Cheshire, is scarcely above high-water mark, forming a low-level plain covered with peat-moss; between it and the sea intervenes a tract of blown sand, forming dunes or "hoes" as they are locally called, which is traversed by the railway from Liverpool to Southport.

" Mem. Geol. Surv. "Geology of Wigan." By E. Hull, F.R.S.

t Mem. Geol. Surv., "Description of go S.E.," and "Geology of the country between Liverpool and Southport." By C. E. De Rance, F.G.S. 
Looking seaward from the train, the eye can descry nothing but range behind range of dunes, the only variety being produced by the irregularity of their heights; the only change from the ceaseless monotony of their yellow slope, the dark green stripes of dwarf willows that serve still more strongly to bring out the sterility o the scene. Leaving the train at Ainsdale, or Hightown, and examining the Lancashire Sahara more closely, it is found to consist of three portions:-a range or series of ranges of sand hills, from one to two miles in breadih. sloping down to the peat-moss, - a central plain,-and a range of sand-hills between the plain and the sea, protecting the former from the latter. Their incoherent masses would, however, be of little avail, were it not for the matted roots of the Sand-reed (Ammophila arumdinacer), locally called "starr-grass," and woven by the people into mats and other articles, and which grass they were unable, until lately, by an old Act of Parliament, to cut or destroy, under the most severe penalties. In the plain, or rather in the series of small oval plains divided from each other by little ridges, running from the sea to the land, there is, in the summer, a dense carpet of spongy moss, mixed with sedges, and sprinkled with flowers. The great quantity of lime constantly set free by the dissolving of marine shells in the sand, causes many of the plants to be of species generally found on a chalk soil. Here occur various plants belonging to the Gentian tribe, as the Perfoliate Yellow-wort (Chlora perfoliaia), the Red Centaury (Erythroa Centaurizm, E. pulchella, and $E$. latifolia). Gentiana Anarella, with its purplish-blue flowers, will be also found about this time. On the adjoining moss-land occurs the rare marsh-gentia, Gentiana Pnezmonanthe, with its large blue bell with five green stripes, With it grows the Buckbean (Menyanthes trifoliata). In the "slacks" (the local name for the little oval plains in the sand-hills), the beautiful Pyrola media occurs in grcat abundance, as does also the Grass of Parnassus (Par nassia palustris.) Each of these slacks has a distinguishing name, as "Bull-rush," "Long," "Mayflower," "Round," and "Dale Slacks :" these in winter receive the drainage of the sand hills, which, being stopped by the carpet of vegetation, forms a series of large standing pools of water, in the midst of apparently porous sand.

To return to the Keuper Marl: it is a series of red, green, and grey marls, with occasional seams of freestone, inuch ripple-marked, and beds of shale, generally with pseudo-morphous crystals of salt, and often veins of fibrous gypsum. Through denudation, the top of it is never seen, and it is thcrefore, with the exception of the Drift, the newest formation in the Liverpool district.

Glacial Drift.- Professor E. Hull, F.R.S., proved (in a paper read at Manchester, in 1862) that the Glacial Drift in the Manchester district was capable of division into an Upper and Lower Boulder Clay, divided by a Middle Sand and Gravel, which he called the "Middle Drift." The writer, in a paper on "Glacial Phenomena of Western Lancashire and Cheshire," read at the last meeting of the Geo logical Society, attempted to prove that this classification holds good, not only in the whole of Western Lancashire, but from the River Dee to the flanks of the Cumberland and Westmoreland Mountains; and since writing that paper he has found that the terrace of Glacial Drift skirting the mountains of North Wales, lying between them and the sea, is capable of that division, the cliffs of boulder clay east of Llandudno (round the Little Orme's Head) being distinctly divided by a Middle Sand, containing the same species of shells as those occurring in the Lancashire Middle Drift.

The Lower Boulder Clay (the writer endeavoured to show, in the paper alluded to above) was formed by an ice-sheet, which covered nearly the whole country down to a level of about 150 feet to 200 above the present sealevel; this clay he termed the "High-level Low Boulder Clay." Below a level of Ico feet, the clay appears to have been formed by the summer melting of an "ice-foot," which surrounded the sea-margin-at that level the land, through subsidence, standing that amount lower than at present. An amelioration of climate then took place during which the sands and gravels of the Miadle Drift, with shells of Celtic type, were deposited round the edges of higher, and still higher, successive coast-lines, as the land gradually sank, until the sand and gravel, at Macclesfield, more than 1,200 feet above the present sea-level, was deposited in water of the same deptr, and containing the same shells, as that in which the middle drift of Blackpool, only fifty feet above the sea was deposited. The phenomena exhibited by the middle drift, of the invariable rise from the sea to the land, in an inclined plane-the undulating surface, now far below, now up to, but never above, that plane-can only be explained by the theory that it was formed as sandbanks in shallow water on a gradually subsiding tract; and the Upbor. Boulder Clay is a marine deposit, formed of the detritus brought donn by glaciers in the valleys of the Cumberland Lake district, to the ice-foot, which melting carried its spoils over the sea-covered plains. All these divisions are more or less well seen in the Liverpool district, especially on the Cheshire side of the river, in the neighbourhood of Egremont and Eastham. Further south, north of Chester, the Midclle Drift is particularly well developed. Most of the boulder clay in North Cheshire belongs to the upper division, the lower clay being absent, having been denuded away. Glacial striæ were discovered by $\mathrm{Mr}$. Morton F.G.S., at Flaybrick Hill, the direction being N. $30^{\circ} \mathrm{W}$. at an elevation of 120 feet above the sea-level; and at Toxteth Park, the direction being N. $42^{\circ} \mathrm{W}$.; also by Mr. Hull, F.R.S., at Kirkdale, the direction N. $15^{\circ} \mathrm{W}$, caused probably by icebergs during the Upper Boulder Clay period.

In the district between Liverpool and Southport a bed of sand occurs, forming a line of old sand hills at the inland edge of the peat-moss plain, and making a sort of step between it and the comparatively high-level (So to 160 feet) boulder-clay plain above. One of these hillocks is called Shirdley Hill; I therefore called the sand the "Shirdley Hill sand." * It is about 30 feet thick, and underlies the later deposits of the peat plain, but rests itself on a thin deposit of what I called the "Lower Peat." Above this sand, and beneath the great bed of peat (Upper Peat), is a bed of grey clay containing freshwater shells, which I called the "Lower Cyclus clay." I have observed it from the Island of Walney, in North Lancashire, to the coast of North Wales, and believe it, as well as the peat above it,

* "Description of Geol. Surg. Map, 90 S.E." and "Post-Glacial Deposits of Western Lancashire and Clicsire," read at last meeting of the Geol. Soc. 
occurs at the bottom of the greater part of the Irish Sca. All along the coast of Lancashire, Cheshire, and to a certain extent North Wales, the peat, with a forest at its base and the clay containing the roots of the trees, may be seen, nowhere so well as at Leasowe, in Cheshire, and at the mouth of the Alt, Hightown, Lancashire (eight or nine miles from Liverpool). In both localities the peat, the forest at the base, and the grey clay below, occupy the country inland, run under the sand dunes, emerge on the coast, and disappear under the sea sand at low-water mark. In North Cheshire the peat is sometimes split into two, a bed of grey clay, with Scrobicularia piperata, being intercalated in the mass. This I consider to have been formed when the Mersey entered the sea, through what is now the gorge of Wallesey Pool. Very near the top of the peat a thin seam of sand occurs, both in Cheshire and Lancashire, containing Tellina Balthica and Cardium edule. I called the zone of $T$. Balthica. The grey clay of the Isle of Man, with Cervus Megaceros, is no doubt of the same age as the "Cyclus Clay" of Lancashire.

Those who visit Hightown will find the peat, which is there from twelve to twenty feet thick, covered on either side of the River Alt with an alluvium which, near the sea, contains Scrobicularic, and inland graduates into a fluviatile deposit, with freshwater shells. They will find the base of the sand dunes, where they rest' on the upper surface of the peat, to be, as at Leasowe, in North Cheshire, a freshwater deposit, which I called the Bythinia tentaculat $a$ sand; it contains thin seams of peat up to a height of eight or ten feet from the base.

My notes are already so long that I abstain from saying anything of the marine fauna of the coast and other matters: those that I have written refer to districts in which the maps, \&c., of the Geological Survey are already published, and I have of course written as a private geologist, stating my individual opinions.

H.M. Geological Survey

\section{E. DE RANCE}

\section{THE SECOND PROVINCIAL MEETING OF THE IRON AND STEEL INSTITUTE}

$7 \mathrm{HE}$ Institute bearing the above name was originated about two years ago, chiefly by the North of England ironmasters, among whom there are many grentlemen who combine in themselves great practical skill and a large amount of scientific knowledge. It was not formally launched into existence till the month of June, 1869 , when the inaugural address was delivered to a meeting of the members, held in the Hall of the Society of Arts, by the president, the Duke of Devonshire, who is intimately and extensively connected with the iron and steel trades through the great works of Barrow-in-Furness, perhaps the greatest Bessemer steel works in the world. The aim of the Institute is to hold two meetings annually-one in London, in the spring, and the other in the country in the autumn. The first provincial meeting was held, about a year ago, in. Middlesborough, the capital of the Cleveland district, the greatest and most scientific iron-making district either in this or any other country. In May last the second metropolitan meeting was held; and now the second provincial meeting has just been held at Merthyr Tydvil, in South Wales. At all these three meetings there have been read papers of very great interest and im- portance, both from a scientific and a practical point of view. Then, taking the experience of the two provincial meetings, the members not only have the benefit of hearing the papers read and of taking part in the discussions to which they give rise, but they also have the opportunity of visiting the numerous works that are thrown open for their inspection, where they can see scientific theories put to practical tests, and where they can compare notes with each other upon the subjects which deeply concern them as practical and professional men. It is well known that "iron sharpeneth iron:" and in these country meetings of the Iron and Steel Institute this wise saw has many apt illustrations. Examples to imitate are seen in abundance; many points are observed that are suggestive and that excite to further improvements in other hands; and in numerous instances things are seen which impart lessons of a totally different sort, inasmuch as they show what errors of commission are to be avoided. Both successes and failures can give instruction to thoughtful minds.

This year's provincial meeting of the Institute, as already indicated, has been held at Merthyr. It opened on the morning of Tuesday, 6th September, in the Temperance Hall of that town, the centre and most important seat of the iron trade of South Wales. After the transaction of some formal business, and the appointment of Mr. Henry Bessemer as the president-elect of the Institute, the business of reading and discussing the papers prepared for the meeting was proceeded with. Altogether there were seven papers set down for reading and discussion on the mornings of Tuesday and Wednesday, the 6 th and 7 th September, which was all the time that could be devoted to that work, as the afternoons were required for visiting and inspecting the works in and immediately around Merthyr, while Thursday and Friday were required for the inspection of works at a distance. One praiseworthy feature in connection with the meetings in Merthyr was the circumstance of printed copies of the papers being in the hands of the members before they were read by the authors. Owing to this arrangement members were generally enabled to come prepared to enter upon the discussion of the papers with intelligence and with some degree of satisfaction. In two instances the papers supplied to the members were accompanied by engravings of the objects described. Both of these features of the Iron and Steel Institute Meeting might be copied with advantage by other learned societies, as they are calculated to impart additional interest to the meetings.

The Iron and Steel Institute already numbers upwards of 350 members, including several peers of the realm, about a dozen members of Parliament, and almost every person in the kingdom who has of late years added to the stock of our knowledge regarding the manufacture, the manipulation, and the use of iron and steel. It has very soon acquired a national importance, and its future prosperity seems to be almost assured. In order to make the Institute more and more useful to the persons who may be connected with it as members, it is intended to publish a Quarterly Journal of the Institute instead of the Transactions. This will commence on the ist of January, 187I, and its contents will be as follow:-

First, the proceedings of the Institute, and of the Council from time to time. Second, the papers and discussions at the general meetings of the Institute. Third, communications from members upon matters of special interest to the trade, which are approved by the Council. Fourth, a quarterly epitome of inventions, discoveries, publications, and proceedings bearing upon the British iron and steel trades. Fifth, a comprehensive report on matters connected with the iron and steel trades in foreign countries. It is very satisfactory to know that the foreign department of the journal will be under the special management of Mr. David Forbes, F.R.S., and that the general editorship will be conducted 